Research Article

\title{
Synthesis and Characterisation of Activated Carbon Obtained from Marula (Sclerocarya birrea) Nutshell
}

\author{
Tafadzwa Mkungunugwa, ${ }^{1}$ Shepherd Manhokwe, ${ }^{1}$ Armistice Chawafambira ${ }^{(D)}{ }^{2}$ \\ and Munyaradzi Shumba ${ }^{3}$ \\ ${ }^{1}$ Department of Food Science and Nutrition, Midlands State University, Private Bag, Gweru 9055, Zimbabwe \\ ${ }^{2}$ Department of Food Science and Technology, Chinhoyi University of Technology, Private Bag, Chinhoyi 7724, Zimbabwe \\ ${ }^{3}$ Department of Chemical Technology, Midlands State University, Private Bag, Gweru 9055, Zimbabwe
}

Correspondence should be addressed to Armistice Chawafambira; achawazie@gmail.com

Received 12 February 2021; Revised 28 April 2021; Accepted 5 May 2021; Published 10 May 2021

Academic Editor: Maria C. Yebra-Biurrun

Copyright (C) 2021 Tafadzwa Mkungunugwa et al. This is an open access article distributed under the Creative Commons Attribution License, which permits unrestricted use, distribution, and reproduction in any medium, provided the original work is properly cited.

\begin{abstract}
Globally, a ninth of people use polluted water sources because an estimated 300-400 Mt of waste and 90\% of sewage are discharged into water bodies from industries and developing countries, respectively. The utilisation of indigenous fruit pits in producing novel adsorbents will greatly benefit in wastewater treatment. In most underdeveloped countries, activated carbon (AC) is imported at a high cost. The study was aimed at synthesising and characterisation of AC obtained from Marula nutshell. Carbonization of organic matter from Marula nutshell was carried out at $200^{\circ} \mathrm{C}, 400^{\circ} \mathrm{C}, 500^{\circ} \mathrm{C}$, and $600^{\circ} \mathrm{C}$. Sulphuric $\left(\mathrm{H}_{2} \mathrm{SO}_{4}\right)$ and phosphoric $\left(\mathrm{H}_{3} \mathrm{PO}_{4}\right)$ acids were used as activating agents at concentrations of $20-60 \%(\mathrm{v} / \mathrm{v})$. Physicochemical characteristics of the $\mathrm{AC}$, such as bulk density, moisture, ash, $\mathrm{pH}$, and iodine number, were analyzed using standard methods. Functional groups and total carbon content were determined using the FTIR spectroscopy and Nitrogen Carbon Sulphur (NCS) analyzer, respectively. The values of carbon yield and total carbon in activated samples with $\mathrm{H}_{2} \mathrm{SO}_{4}$ and $\mathrm{H}_{3} \mathrm{PO}_{4}$ were 32.2-93.2\%, 26.9-95.8\%, and 46-79\%, 20.8-69.8\%, respectively. The $\mathrm{pH}$, ash, moisture, and bulk density of activated high carbon samples with $\mathrm{H}_{2} \mathrm{SO}_{4}$ ranged from $2.4-6.1,0.65-3.49 \%, 1.3-8.4 \%$, and $0.42-0.62 \mathrm{gcm}^{-3}$, respectively. Activated high carbon samples with $\mathrm{H}_{3} \mathrm{PO}_{4}$ had 2.7-3.2, $11.3-29.8 \%, 4.7-14.6 \%$, and $0.39-0.54 \mathrm{gcm}^{-3} \mathrm{pH}$, ash, moisture, and bulk density, respectively. The synthesised AC samples with $40 \% \mathrm{H}_{3} \mathrm{PO}_{4}$ at $500^{\circ} \mathrm{C}$ had the highest iodine value of $1075.7 \mathrm{mg} / \mathrm{g}$. FTIR results showed the presence of aliphatic carboxylic acid salt, inorganic nitrate $\left(\mathrm{NO}^{3-}\right)$, and phosphate groups in the synthesised AC and were not significantly different $(p<0.05)$ from commercial AC. The untreated Marula nutshell had some aliphatic hydrocarbon (alkanes), inorganic phosphate $\left(\mathrm{PO}_{4}^{3-}\right)$, aliphatic ester $(-\mathrm{COO})$, and aliphatic carboxylic acid salt $(-\mathrm{C}(=\mathrm{O}) \mathrm{O}-)$ groups. A novel adsorbent, $\mathrm{AC}$ was produced from Marula nutshell with the potential to be used in water treatment.
\end{abstract}

\section{Introduction}

Activated carbon is a term that refers to a family of carbonaceous solid material resulting from biomass, coal, and polymer scrap through thermal or thermochemical processes [1]. AC are nanoporous adsorbents in nature and play an important role in both gas and liquid phase separation processes [2]. AC is characterised by a well-formed pore morphology, high surface area, electron-conducting amphoteric property, and high adsorptive capacity [3]. The chemical properties of AC are well-defined by the composition of its surface groups and the chemical bonding of heteroatoms [1]. Characteristics of AC are influenced by the physical and chemical properties of the raw materials plus the method of activation $[4,5]$. The functional groups determine the important characteristics of the activated carbon, such as acidity, hydrophobicity, polarisation intensity, and adsorption properties [6]. AC is widely used in different 
fields further than adsorption to wastewater treatment, solvent recovery, air pollution control, and other industrial effluents $[1,6]$, which pose major health risks [7].

Marula (Sclerocarya birrea subsp. caffra) is an indigenous fruit tree (IFT) in Africa and belongs to the family Anacardiaceae $[8,9]$. Marula is a deciduous tree with a height of $7-18 \mathrm{~m}$ and grows well in semi and dry areas in sub-Saharan Africa $[10,11]$. The tree is most abundant in eastern Africa (Kenya, Tanzania), southern Africa (Angola, Botswana, Namibia, Malawi, Mozambique, South Africa, and Swaziland) $[12,13]$. The tree produces about approximately $500 \mathrm{~kg}$ of ripe fruits per year which have a gelatinous thick, gluey substance with a sweetly acid taste [14]. The fruits and seed have been used in producing cooking oils, jam, jelly and other tree parts have medicinal properties for treatment of diseases [15]. The extensive use of Marula fruit and seed has resulted in the nutshells (seed husk) often discarded as an agricultural waste material which causes pollution of the environment [15].

In recent years, the demand and marketing of AC has grown due to the problems of water pollution globally $[16,17]$. Adsorption has been reported to be an efficient separation technique for removing harmful heavy metals from water [17].

The increased demand for adsorbents has led to much researches on the utilisation of available carbonaceous materials in the synthesis of activated carbon. Studies have been conducted on the use of different agricultural byproducts in the syntheses of activated carbon $[1,18-20]$. Pavlenko et al. [21] indicated other benefits of AC in hemoperfusion, dressing of wounds with pus, and removal of endogenous and exogenous toxins in uraemia.

Commercial activated carbon (CAC) on the market remains an expensive material for wastewater treatment. The hard shell of the Marula nut can be processed into a novel carbonaceous adsorbent. Therefore, this research was aimed at synthesising and characterising AC produced from Marula nutshell with the potential to be used in water purification in Zimbabwe.

\section{Materials and Methods}

2.1. Sampling and Treatment of Marula Nutshells. Marula nuts were collected from Shurugwi district (a semidry area located $30^{\circ} \mathrm{S} 19^{\circ} \mathrm{E}$ in Agro farming region 3 and has sandy soils in Zimbabwe) as shown in Figure 1. The collected nuts were crushed and the germ separated manually from the shell. The shells were then washed with distilled water and rinsed with $0.3 \mathrm{M} \mathrm{HCl}$ to remove impurities such as metal ions and surface adhering dirt particles. The shells were then soaked in $0.1 \mathrm{M} \mathrm{NaOH}$ solution for $24 \mathrm{hr}$ to remove lignin, followed by soaking for $2 \mathrm{hr}$ in $0.1 \mathrm{M}$ acetic acid to balance the $\mathrm{pH}$. The shells were then washed with distilled water and then dried at $105^{\circ} \mathrm{C}$ in a Gallenkamp oven for $72 \mathrm{hr}$ to completely remove the moisture and other volatiles [5]. The dried shells were then pulverized into a fine powder using a laboratory mill and sieved using an $1180 \mu \mathrm{m}$ sieve to achieve homogeneity [22]. The milled Marula nutshell powder was then placed in tightly closed, clean polythene bags and stored at room temperature, awaiting further use.

\subsection{Carbonization and Chemical Activation of Milled Marula} Nutshell. The milled Marula nutshell powder $(5 \mathrm{~g})$ was weighed and mixed with $15 \mathrm{ml}$ of $0 \%, 20 \%, 40 \%$, and $60 \%$ $\mathrm{H}_{3} \mathrm{PO}_{4}$ and left to soak for $2 \mathrm{hr}$. The same process was carried out using $\mathrm{H}_{2} \mathrm{SO}_{4}$. The mixtures were then placed in a Gallenkamp oven set at $100^{\circ} \mathrm{C}$ for a further $2 \mathrm{hr}$. The activation process of the samples was then conducted by heating at $300^{\circ} \mathrm{C}$ for $2 \mathrm{hr}, 400^{\circ} \mathrm{C}$ for $2 \mathrm{hr}, 500^{\circ} \mathrm{C}$ for $1 \mathrm{hr}$, and $600^{\circ} \mathrm{C}$ for $1 \mathrm{hr}[5,23]$. The synthesised AC samples were then cooled to room temperature $\left(26^{\circ} \mathrm{C}\right)$ in a desiccator. The cooled AC samples were then soaked in $1 \mathrm{M} \mathrm{NaOH}$ to neutralize the acid and thoroughly washed with distilled water. The samples were then dried in a Gallenkamp (Plus II Oven, UK) oven at $105^{\circ} \mathrm{C}$ for $24 \mathrm{hr}$ and packed in tightly closed clean polythene bags.

2.3. Carbon Yield Analysis. The carbon yield was calculated by weighing the mass of the AC and dividing it by the total weight of the sample before the carbonization process. It was expressed as a percentage on a dry matter basis as follows:

$$
\text { yield }(\%)=\frac{\text { weight of activated carbon }}{\text { weight of raw material }} \times 100 \text {. }
$$

2.4. Total Carbon Content. A milled sample of $2 \mathrm{mg}$ was weighed into a tin container using a microspatula. The tin container was then folded lightly to ensure it does not break using roller tongs. Two blank containers were also folded and transferred into the first Nitrogen Carbon Sulphur (NCS) analyzer cells (Flash 2000 NCS, Thermo Scientific, Waltham, MA USA). A suitable method profile was selected on the NCS analyzer method sheet provided and samples were imputed into the sample table. Conditions for analyses were set following NCS analyzer operating instructions and analyses were then initiated. After a full combustion cycle, results were automatically transmitted in a digital result spreadsheet.

\subsection{Physicochemical Characterisation of Activated Carbon} Samples. The samples that contained high carbon contents were analyzed for the following physicochemical properties:

2.5.1. Bulk Density. The density of the AC was determined following a method (D2854-96, 2000) by ASTM [23] with slight modifications. The sample was poured into a glass container of a known volume and the mass measured. The density was calculated as follows:

$$
\text { density }\left(\frac{g}{\mathrm{ml}}\right)=\frac{\text { mass of activated carbon }(g)}{\text { volume of activated carbon }(\mathrm{ml})} \text {. }
$$




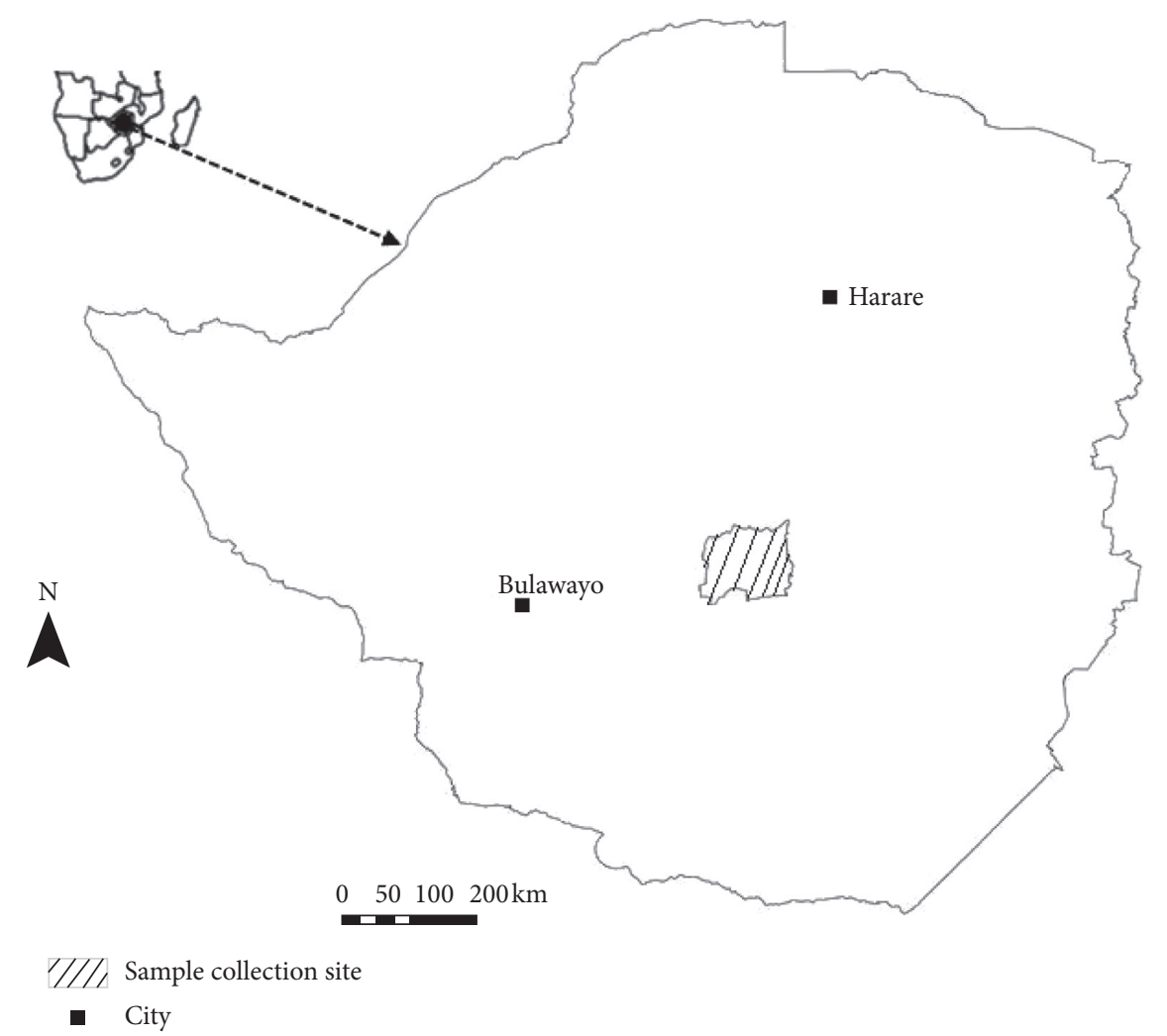

FIgURE 1: Map showing Marula nuts collection area of Shurugwi district, Zimbabwe.

2.5.2. Moisture Content. Moisture was determined using a standard method for analyzing moisture in AC by ASTM D 2867 [24]. Moisture content was calculated as follows:

$$
\text { moisture }(\%)=\left(\frac{C-D}{C-B}\right) \times 100
$$

where $B=$ Weight of empty crucible, $C=$ weight of crucible + sample $(g), D=$ weight of crucible with cover + dry sample $(g)$.

2.6. Ash Content (on a Dry Basis). Ash content was determined following a method ASTM D2866-11 by ASTM [25] as follows:

$$
\text { total ash }(\%)=\left(\frac{D-B}{C-B}\right) \times 100 \text {, }
$$

where $B=$ weight of crucible $(g), C=$ weight of crucible + original sample $(g)$, and $D=$ weight of crucible + ashed sample $(g)$.

2.7. $\mathrm{pH}$ Analysis. The $\mathrm{pH}$ was measured using a method described by Abdullah et al. [26] using an Ion and $\mathrm{pH}$ meter (GLP ${ }^{22}$, Crison instruments, South Africa).

2.8. Iodine Number. The iodine number was measured following a method described by Abdullah et al. [26] with slight modifications. A sample of $1 \mathrm{~g}$ AC was mixed with $10 \mathrm{~mL}$ of $5 \%(w / v)$ of HCL and heated up to a boiling point.
The mixture was then cooled to room temperature and $100 \mathrm{~mL}$ of $0.1 \mathrm{~N}$ Iodine was added. The resulting mixture was then vigorously shaken and filtered. The filtrate $(25 \mathrm{~mL})$ was then titrated against a $0.1 \mathrm{~N}$ Sodium thiosulphate in the presence of a starch indicator.

2.9. FTIR Analysis. The Fourier transform infrared (FTIR) analysis of the samples was carried out by FTIR equipment (Nicolet 6700, Thermo Scientific, Waltham, MA USA) incorporated with software (Perkin Elmer Instruments version 3.02.01) for the examination of the spectra. The high carbon sample with the highest iodine value was analyzed. A $1 \mathrm{mg}$ of synthesised AC sample was collected mixed with $100 \mathrm{mg}$ $\mathrm{KBr}$ and ground into a fine powder. The powder was then compressed into a pellet and then introduced into the spectrophotometer for analysis. The spectra were scanned over the wavenumber range of 4000 and $500 \mathrm{~cm}^{-1}$. The same procedure was also carried out for the untreated Marula nutshell and commercial AC.

2.10. Statistical Analysis. The results of physical and chemical characteristics of AC were expressed as mean\pm standard deviation (SD). All experiments were conducted in triplicate and analysis was carried out using SPSS package version 18.0 (Coakes and Ong, John Wiley \& Sons, Queensland, Australia). The least significant difference (LSD) test was conducted and one-way Analysis of Variance (ANOVA) was performed at $p<0.05$. 


\section{Results and Discussion}

Yield results of AC from different treatments are shown in Tables 1 and 2. The observed results indicated that the yield of activated carbon tends to increase with the increase in the concentration of reducing agents. Research by Chen [27] has shown that the activating agent digests the amorphous lignin in the plant material. In AC synthesis, the occurrence of hemicellulose, a cross-linked polymer with other sugars such as arabinose, glucose, galacturonic acid, mannose, O-methyl-glucuronic acid, and xylose is of importance [1]. The presence of hydrogen bonding and crystallinity in natural cellulose has been reported to contribute to the lower adsorption capacity; hence, its capacity can be improved by modifying its structure using chemicals [28].

The AC synthesised at $200^{\circ} \mathrm{C}$ and activated using $\mathrm{H}_{2} \mathrm{SO}_{4}$ had a decreased yield as the concentration of the reducing agent was increased. The yield of AC is affected by the temperature at which the carbonation process occurs. Danish and Ahmad [28] reported that the thermal decomposition of hemicellulose occurs above $200^{\circ} \mathrm{C}$, and in the range of $250-400^{\circ} \mathrm{C}, \mathrm{CO}$ and $\mathrm{CO}_{2}$ are released from the glucopyranose rings. This is then followed by the decomposition of cellulose [1].

During the synthesis of activated carbon, the activating agents inhibit tar formation and hence lead to an increased yield with increasing concentration [29]. Also, an increase in the concentration of the reducing agent reduces excessive sample burn-off and hence leads to high yield [30]. This could support the observed results on the high carbon yield on samples activated using $\mathrm{H}_{2} \mathrm{SO}_{4}$ at $200^{\circ} \mathrm{C}$. The reactivity of the chemical activating agent under high heating conditions creates an intermolecular reaction on the biomass and result in an efficient activated carbon production [1].

The carbon yield for the three treatments with $20 \%, 40 \%$, and $60 \% \mathrm{H}_{2} \mathrm{SO}_{4}$ ranged between 15.6 and $93.2 \%$ with a high yield obtained at $200^{\circ} \mathrm{C}$ (Table 1 ). The lowest carbon yield was obtained at $400^{\circ} \mathrm{C}$ using $\mathrm{H}_{2} \mathrm{SO}_{4}$. It was observed that the carbon yield for samples activated using $60 \% \mathrm{H}_{2} \mathrm{SO}_{4}$ decreased with an increase in temperature from $200^{\circ} \mathrm{C}$ to $400^{\circ} \mathrm{C}$ and then gradually increased thereafter. This implies that an increase in acid concentration and the activation temperature have a positive effect on the yield of AC. However, the results of $\mathrm{H}_{3} \mathrm{PO}_{4}$ showed a different trend (Table 2). Though the highest carbon yield was also obtained at $200^{\circ} \mathrm{C}$, a further increase in temperature resulted in a decrease and later an increase in carbon yield. It can, however, be reported in this study that samples activated using $\mathrm{H}_{3} \mathrm{PO}_{4}$ at $500^{\circ} \mathrm{C}$ produced a high carbon yield. $\mathrm{H}_{3} \mathrm{PO}_{4}$ undergoes polymerisation with epoxides, other polymerisable mixtures, and can break lignocellulose into lignin and cellulose [31]. The $\mathrm{H}_{3} \mathrm{PO}_{4}$ can directly react with lignin and breaks down hemicellulose and cellulose found in the biomass of the plant into monomeric sugars [1]. Örkün et al. [32] reported the effectiveness of using different concentrations of $\mathrm{H}_{3} \mathrm{PO}_{4}$ on the development of pores, improved morphology, surface chemistry, and size distribution of AC synthesised from hazelnut shells. Huang et al. [33] showed that $\mathrm{H}_{3} \mathrm{PO}_{4}$ could break bonds, dissociates aliphatic, and aromatic molecules in biomasses, thereby promoting the removal of volatile substrates and causing partial aromatisation and carbonization.

Nwabanne and Igbokwe [34] reported a high carbon yield from nipa palm nuts that were treated with $\mathrm{H}_{3} \mathrm{PO}_{4}$ (172.4 g) as compared to $\mathrm{H}_{2} \mathrm{SO}_{4}(196.6 \mathrm{~g})$. Our results also indicated no carbon in Marula nutshell samples that were not activated with acid but heated at $400^{\circ} \mathrm{C}, 500^{\circ} \mathrm{C}$, and $600^{\circ} \mathrm{C}$. It can be explained that at such high temperatures, burning off of the samples occurred because of the absence of acids (activating agents). More so, the acid (activating agents) tends to bind to the carbon and other compounds in the samples and prevent burn-off.

The total carbon content of the synthesised AC samples is shown in Table 3. Results observed indicated that samples activated using $\mathrm{H}_{2} \mathrm{SO}_{4}$ and $\mathrm{H}_{3} \mathrm{PO}_{4}$ at $200^{\circ} \mathrm{C}$ had a high carbon content of $79 \%$ and $69.8 \%$, respectively (Table 3 ). The low carbon content $(20.8 \%$ and $46 \%)$ was obtained in samples synthesised at $400^{\circ} \mathrm{C}$ with $40 \% \mathrm{H}_{3} \mathrm{PO}_{4}$ and $\mathrm{H}_{2} \mathrm{SO}_{4}$, respectively. The heating process led to the burning off of noncarbon material and might have led to an increased carbon content per weight of the sample used. Also, during the synthesis of $\mathrm{AC}$, the acids were critical in retaining the carbon in the samples. This is supported by Nicolae et al. [35] who reported that dehydrating agents such as acids used during the carbonization stage tend to promote bond cleavage reactions and the formation of cross-linkages with organic compounds in the sample while the noncarbon material undergoes the process of devolution.

\subsection{Physicochemical Characterisation of Activated Carbon.} The untreated Marula nutshell samples had a carbon content, $\mathrm{pH}$, moisture, ash, bulk density, and iodine value of $38.2 \pm 0.01 \%, 5.5 \pm 0.1,8.4 \pm 0.02 \%, 12.1 \pm 0.1 \%, 0.64 \pm$ $0.01 \mathrm{gcm}^{-3}$, and $943.8 \pm 0.01 \mathrm{mg} / \mathrm{g}$, respectively, as shown in Table 4 . There was no significant difference $(p<0.05)$ in the bulk density of the untreated Marula nutshell and commercial AC on the market.

The $\mathrm{pH}$ of the Marula nutshells and commercial type AC were 5.8 and 4.8, respectively, as shown in Table 4 . The $\mathrm{pH}$ values for the synthesised high carbon-containing samples activated using $\mathrm{H}_{2} \mathrm{SO}_{4}$ and $\mathrm{H}_{3} \mathrm{PO}_{4}$ at different temperatures $\left(200-600^{\circ} \mathrm{C}\right)$ ranged from $2.4-6.1$ and $2.8-3.2$, respectively (Table 5). High carbon samples activated with $40 \% \mathrm{H}_{2} \mathrm{SO}_{4}$ at $400^{\circ} \mathrm{C}$ had a high ash content of $51 \%$ and samples activated using $40 \% \mathrm{H}_{3} \mathrm{PO}_{4}$ at $500^{\circ} \mathrm{C}$ had a $29.8 \%$ ash content. The ash contents in samples activated using $\mathrm{H}_{2} \mathrm{SO}_{4}$ were lower as compared to the commercial sample. The low ash and moisture content in the AC showed a low particle density and the biomaterial could be a good raw material for adsorbents in reactors $[20,36]$. The moisture content of all high carbon samples activated using both $\mathrm{H}_{3} \mathrm{PO}_{4}$ and $\mathrm{H}_{2} \mathrm{SO}_{4}$ was higher as compared to commercial AC samples (0.1). This study also observed that the bulk density and iodine values of the synthesised high carbon samples were not significantly different $(p<0.05)$ from the commercial AC and Marula nutshell samples.

The ash content of the synthesised carbon samples was generally low. This study also noted a relationship between 
TABLE 1: Yield of activated carbon from $\mathrm{H}_{2} \mathrm{SO}_{4}$ treatment.

\begin{tabular}{|c|c|c|c|c|c|}
\hline \multirow{2}{*}{ Acid (\%) } & \multicolumn{4}{|c|}{ Temperature $\left({ }^{\circ} \mathrm{C}\right)$} & \multirow{2}{*}{$p$ value } \\
\hline & 200 & 400 & 500 & 600 & \\
\hline Control* & $83.0 \pm 0.01$ & NY & NY & NY & ns \\
\hline 20 & $82.9 \pm 0.01^{\mathrm{a}}$ & $15.6 \pm 0.01^{\mathrm{b}}$ & $33.1 \pm 0.02^{\mathrm{c}}$ & $39.8 \pm 0.01^{\mathrm{c}}$ & $<0.05$ \\
\hline 40 & $83.4 \pm 0.01^{\mathrm{a}}$ & $19.8 \pm 0.02^{\mathrm{b}}$ & $32.2 \pm 0.01^{\mathrm{c}}$ & $40.6 \pm 0.01^{\mathrm{c}}$ & $<0.05$ \\
\hline 60 & $93.2 \pm 0.02^{\mathrm{a}}$ & $28.5 \pm 0.01^{\mathrm{b}}$ & $38.0 \pm 0.02^{\mathrm{c}}$ & $41.5 \pm 0.01^{\mathrm{c}}$ & $<0.05$ \\
\hline
\end{tabular}

${ }^{*}=$ distilled water, $\mathrm{NY}=$ no yield; $\mathrm{ns}=$ not significant; mean \pm standard deviations are reported. Means in a row with different superscripts $\left({ }^{\mathrm{a}, \mathrm{b}, \mathrm{c}}\right)$ are significantly different at $p<0.05$.

TABLE 2: Yield of activated carbon from $\mathrm{H}_{3} \mathrm{PO}_{4}$ treatment.

\begin{tabular}{|c|c|c|c|c|c|}
\hline \multirow{2}{*}{ Acid (\%) } & \multicolumn{4}{|c|}{ Temperature $\left({ }^{\circ} \mathrm{C}\right)$} & \multirow{2}{*}{$p$ value } \\
\hline & 200 & 400 & 500 & 600 & \\
\hline Control* & $95.8 \pm 0.01$ & NY & NY & NY & ns \\
\hline 20 & $73.6 \pm 0.02^{\mathrm{a}}$ & $38.4 \pm 0.02^{\mathrm{b}}$ & $45.1 \pm 0.01^{\mathrm{b}}$ & $26.9 \pm 0.02^{c}$ & $<0.05$ \\
\hline 40 & $77.0 \pm 0.01^{\mathrm{a}}$ & $52.9 \pm 0.01^{\mathrm{b}}$ & $67.9 \pm 0.01^{\mathrm{c}}$ & $45.8 \pm 0.01^{\mathrm{b}}$ & $<0.05$ \\
\hline 60 & $68.4 \pm 0.01^{\mathrm{a}}$ & $52.8 \pm 0.02^{\mathrm{b}}$ & $66.6 \pm 0.02^{\mathrm{a}}$ & $60.6 \pm 0.02^{\mathrm{a}}$ & $<0.05$ \\
\hline
\end{tabular}

${ }^{*}=$ distilled water, $\mathrm{NY}=$ no yield; $\mathrm{ns}=$ not significant; mean \pm standard deviations are reported. Means in a row with different superscripts $\left({ }^{\mathrm{a}, \mathrm{b}, \mathrm{c}}\right)$ are significantly different at $p<0.05$.

ash content, bulk density, and total carbon content. Activate samples with low ash and bulk density tend to have a high total carbon content. Ekpete et al. [20] reported the effects of ash content on the ignition point of the carbon and it reduces the overall activity and efficiency of the reactivation of the AC. More so, a low ash value would improve the property of the activated carbon as an adsorbent. The lower ash content in the synthesised AC would possibly make it a good adsorbent. Abdullah et al. [26] reported that a high ash content is undesirable for $\mathrm{AC}$ since it reduces the mechanical strength of carbon and affects adsorptive capacity. Also, high ash content can reduce the adsorption power of AC due to the presence of minerals such as $\mathrm{Ca}, \mathrm{Na}, \mathrm{K}$, and $\mathrm{Mg}$, which tend to fill the pores of activated carbon [1].

The iodine value ranged between $915-1075 \mathrm{mg} / \mathrm{g}$ in the synthesised AC samples (Table 5). AC samples activated using $40 \% \mathrm{H}_{3} \mathrm{PO}_{4}$ at $500^{\circ} \mathrm{C}$ had the highest iodine value of $1075.7 \mathrm{mg} / \mathrm{g}$. The iodine number can be used to estimate the surface area of the $\mathrm{AC}$ in $\mathrm{m}^{2} / \mathrm{g}$ and it measures the porosity within the dimensions [20]. The higher iodine value of AC has been ascribed to the occurrence of a large micropore structure that can result in the carbon having a large surface area because of the enlargement of its pore structure [37]. The observed iodine values make it possible for use in water treatment. Verla et al. [5] reported that $\mathrm{AC}$ with an iodine range of $600-1100 \mathrm{mg} / \mathrm{g}$ could be recommended for use in water treatment. The iodine values of the synthesised AC were comparable to that of the commercial $\mathrm{AC}$ $(1034.3 \pm 0.02 \mathrm{mg} / \mathrm{g})$ on the market.

Furthermore, the iodine value, however, tends to increase with an increase in carbon content in samples activated with $\mathrm{H}_{2} \mathrm{SO}_{4}$ and heat-treated at $200^{\circ} \mathrm{C}$ but was different in samples heated at $500^{\circ} \mathrm{C}$. This could be explained by the extent of pore formation in the synthesis of the activated carbon at these different conditions. AC samples activated using $\mathrm{H}_{3} \mathrm{PO}_{4}$ had higher carbon content and also high iodine values when compared to samples activated using $\mathrm{H}_{2} \mathrm{SO}_{4}$. This could be explained by the differences in reactivity rate with the activating agents [6]. The differences in the iodine number between untreated Marula nutshell carbon and synthesised AC could be attributed to the chemisorption which might have taken place in the pores of the carbons during carbonization and activation, resulting in the development of large micropores $[6,37]$.

Novel AC from Marula nutshell had a significantly high iodine value $(1075.7 \mathrm{mg} / \mathrm{g})$ and yield of the AC (45.8-77.0 wt\%) when compared with adsorbents produced from tire and tamarind seeds. Li et al. [38] observed an iodine value and carbon yield of $352 \mathrm{mg} / \mathrm{g}$ and $39.8 \mathrm{wt} \%$ in AC from tire char, respectively. Another study by Sharada et al. [39] reported that AC synthesised from tamarind seeds has a $\mathrm{pH}(7.0)$, moisture content $(2.9 \%)$, ash (1.5\%), bulk density $\left(0.4 \mathrm{~g} / \mathrm{cm}^{3}\right)$, iodine number $(995 \mathrm{mg} / \mathrm{g})$, and specific surface area $\left(912 \mathrm{~m}^{2} / \mathrm{g}\right)$. Furthermore, Mopoung et al. [40] reported a carbon yield of 54.09-82.03 wt\% from AC produced from tamarind seeds activated with $\mathrm{KOH}$. Although the carbon content was lower in the synthesised AC as compared to other adsorbents, it has the potential to be used as a good adsorbent in removing harmful compounds in water.

3.2. FTIR Characterisation. FTIR analysis results are indicated in Figures 2-4. FTIR analysis was used to identify the functional groups and other chemical compounds present in the activated carbon, which are important in its characterisation and forecasting adsorption performance [20]. The surface chemistry of untreated Marula nutshell samples was observed to have an FTIR spectrum within $3400 \mathrm{~cm}^{-1}$ correlated to a primary amine group $(\mathrm{N}-\mathrm{H})$, and the small band at $2950 \mathrm{~cm}^{-1}$ showed the presence of an alkane (Figure 2). More so, untreated Marula nutshell indicated the presence of an anhydride group $(\mathrm{CO}-\mathrm{O}-\mathrm{CO})$ at a band of 


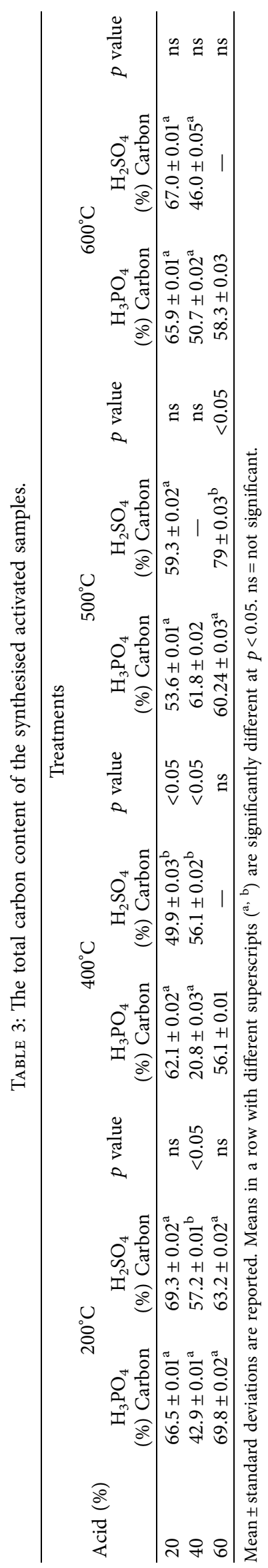


TABLE 4: Physicochemical properties of Marula nutshell and commercial carbon.

\begin{tabular}{lcccccc}
\hline Sample & Carbon (\%) & $\mathrm{pH}$ & Moisture (\%) & Ash (\%) & Bulk density $\left(\mathrm{gcm}^{-3}\right)$ & Iodine value $(\mathrm{mg} / \mathrm{g})$ \\
\hline Marula nut shell & $38.2 \pm 0.01^{\mathrm{a}}$ & $5.5 \pm 0.1^{\mathrm{a}}$ & $8.4 \pm 0.02^{\mathrm{a}}$ & $12.1 \pm 0.1^{\mathrm{a}}$ & $0.64 \pm 0.01^{\mathrm{a}}$ & $943.8 \pm 0.01^{\mathrm{a}}$ \\
Commercial carbon & $76.9 \pm 0.01^{\mathrm{b}}$ & $4.8 \pm 0.1^{\mathrm{a}}$ & $0.1 \pm 0.01^{\mathrm{b}}$ & $13.8 \pm 0.2^{\mathrm{a}}$ & $0.54 \pm 0.02^{\mathrm{a}}$ & $1034.3 \pm 0.02^{\mathrm{b}}$ \\
$p$ value & $<0.05$ & $<0.05$ & $<0.05$ & $\mathrm{~ns}$ & $\mathrm{~ns}$ & $<0.05$ \\
\hline
\end{tabular}

Mean \pm standard deviations are reported. Means in a column with different superscripts ${ }^{\mathrm{a}, \mathrm{b}}$ ) are significantly different at $p<0.05$.

TAвle 5: Physicochemical characterisation of the synthesised high carbon samples.

\begin{tabular}{|c|c|c|c|c|c|c|}
\hline \multirow{2}{*}{ Temperature $\left({ }^{\circ} \mathrm{C}\right)$} & \multirow{2}{*}{ Acid (\%) } & \multicolumn{5}{|c|}{ Physicochemical properties } \\
\hline & & $\mathrm{pH}$ & Moisture (\%) & Ash (\%) & Bulk density $\left(\mathrm{g} / \mathrm{cm}^{3}\right)$ & Iodine value $(\mathrm{mg} / \mathrm{g})$ \\
\hline \multicolumn{7}{|l|}{$\mathrm{H}_{2} \mathrm{SO}_{4}$ treatments: } \\
\hline \multirow{4}{*}{200} & 20 & $2.9 \pm 0.1^{\mathrm{a}}$ & $2.4 \pm 0.2^{\mathrm{a}}$ & $0.65 \pm 0.01^{\mathrm{a}}$ & $0.62 \pm 0.02^{\mathrm{c}}$ & $1036.1 \pm 0.01^{\mathrm{c}}$ \\
\hline & 40 & $3.9 \pm 0.1^{b}$ & $1.3 \pm 0.1^{\mathrm{a}}$ & $3.49 \pm 0.01^{\mathrm{b}}$ & $0.53 \pm 0.01^{\mathrm{a}}$ & $938.5 \pm 0.11^{\mathrm{a}}$ \\
\hline & 60 & $2.4 \pm 0.1^{\mathrm{a}}$ & $10.7 \pm 0.2^{\mathrm{c}}$ & $0.97 \pm 0.01^{\mathrm{a}}$ & $0.54 \pm 0.02^{\mathrm{a}}$ & $947.4 \pm 0.12^{\mathrm{a}}$ \\
\hline & 40 & $6.1 \pm 0.1^{\mathrm{c}}$ & $3.9 \pm 0.1^{b}$ & $51.0 \pm 0.01^{\mathrm{c}}$ & $0.43 \pm 0.01^{\mathrm{a}}$ & $1024.3 \pm 0.10^{c}$ \\
\hline \multirow[t]{2}{*}{400} & 20 & $5.7 \pm 0.1^{\mathrm{c}}$ & $2.8 \pm 0.2^{\mathrm{a}}$ & $3.79 \pm 0.01^{\mathrm{b}}$ & $0.42 \pm 0.01^{\mathrm{a}}$ & $1036.1 \pm 0.12^{c}$ \\
\hline & 40 & $5.7 \pm 0.1^{\mathrm{c}}$ & $3.3 \pm 0.1$ & $4.62 \pm 0.2^{\mathrm{b}}$ & $0.43 \pm 0.02^{\mathrm{a}}$ & $915.2 \pm 0.01^{\mathrm{a}}$ \\
\hline 500 & 60 & $6.1 \pm 0.1^{\mathrm{c}}$ & $2.5 \pm 0.2^{\mathrm{a}}$ & $4.53 \pm 0.01^{\mathrm{b}}$ & $0.45 \pm 0.01^{\mathrm{a}}$ & $990.8 \pm 0.15^{\mathrm{a}}$ \\
\hline p value & & $<0.05$ & $<0.05$ & $<0.05$ & $<0.05$ & $<0.05$ \\
\hline \multicolumn{7}{|l|}{$\mathrm{H}_{3} \mathrm{PO}_{4}$ treatments: } \\
\hline 200 & 60 & $2.8 \pm 0.1^{\mathrm{a}}$ & $6.4 \pm 0.2^{\mathrm{a}}$ & $14.2 \pm 0.01^{\mathrm{a}}$ & $0.54 \pm 0.01^{\mathrm{a}}$ & $1042.6 \pm 0.10^{\mathrm{a}}$ \\
\hline 400 & 20 & $3.2 \pm 0.1^{b}$ & $6.6 \pm 0.1^{\mathrm{a}}$ & $14.2 \pm 0.01^{\mathrm{a}}$ & $0.42 \pm 0.02^{\mathrm{a}}$ & $1048.3 \pm 0.14^{\mathrm{a}}$ \\
\hline 500 & 40 & $2.7 \pm 0.1^{\mathrm{a}}$ & $14.6 \pm 0.1^{\mathrm{b}}$ & $29.8 \pm 0.01^{\mathrm{b}}$ & $0.82 \pm 0.01^{b}$ & $1075.7 \pm 0.11^{\mathrm{a}}$ \\
\hline 600 & 20 & $3.2 \pm 0 .^{b}$ & $4.7 \pm 0.2^{\mathrm{a}}$ & $11.3 \pm 0.01^{\mathrm{a}}$ & $0.39 \pm 0.02^{\mathrm{a}}$ & $1131.9 \pm 0.13^{b}$ \\
\hline$p$ value & & $<0.05$ & $<0.05$ & $<0.05$ & $<0.05$ & $<0.05$ \\
\hline
\end{tabular}

Mean \pm standard deviations are reported. Means in a column with different superscripts $\left({ }^{\mathrm{a}, \mathrm{b}}{ }^{\mathrm{c}} \mathrm{c}\right)$ are significantly different at $p<0.05$.

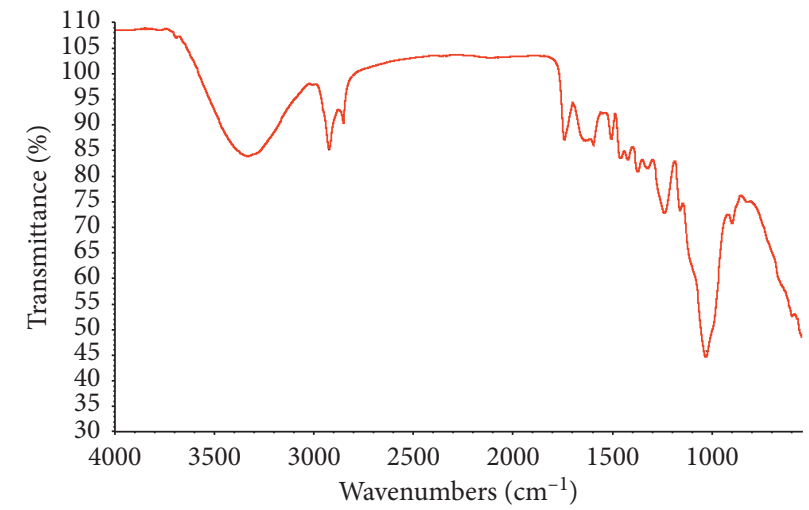

FIGURE 2: FTIR wavenumbers for untreated Marula nutshell.

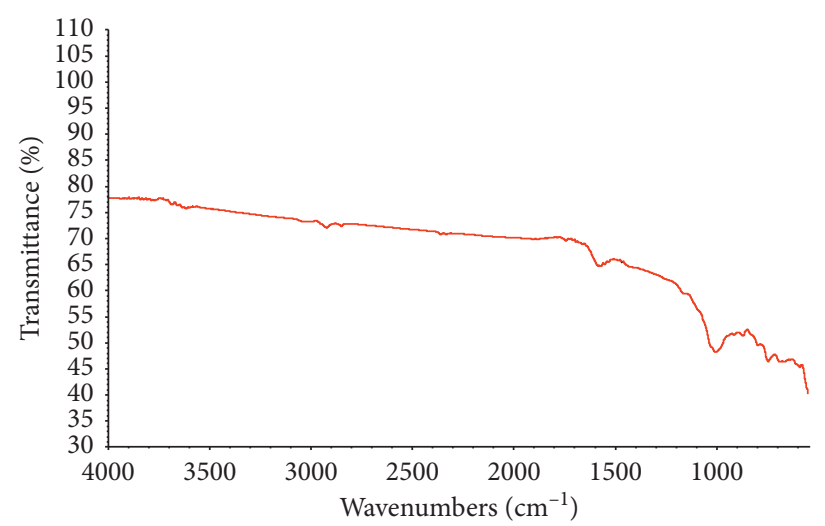

FIGURE 3: FTIR wavenumbers for commercial AC. 


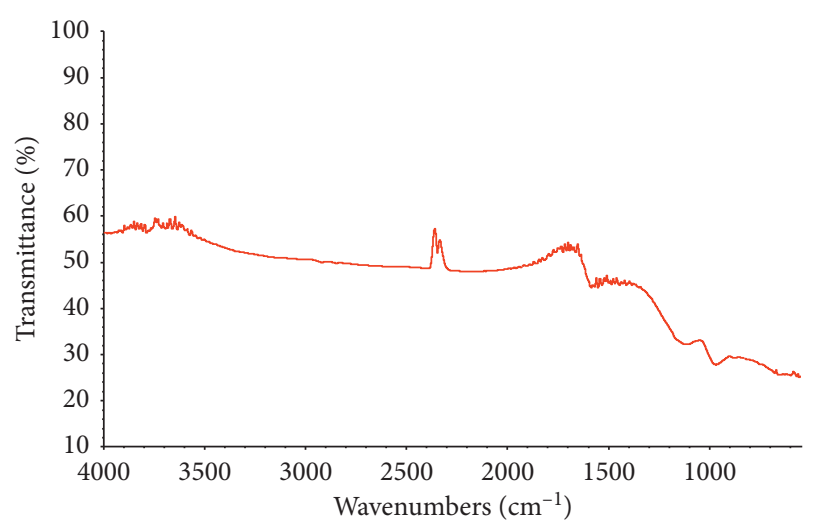

FIGURE 4: FTIR wavenumbers for synthesised $\mathrm{AC}\left(40 \% \mathrm{H}_{3} \mathrm{PO}_{4}\right.$ at $500^{\circ} \mathrm{C}$ ).

$1025 \mathrm{~cm}^{-1}$. Commercial AC had weak bands at 2900, 1000, 750 , and $1550 \mathrm{~cm}^{-1}$, which represented the presence of some small aliphatic hydrocarbon (alkanes), inorganic phosphate $\left(\mathrm{PO}^{43}-\right)$, aliphatic ester (-COO), and aliphatic carboxylic acid salt $(-\mathrm{C}(=\mathrm{O}) \mathrm{O}-)$ groups (Figure 3$)$. The synthesised activated carbon with $40 \% \mathrm{H}_{3} \mathrm{PO}_{4}$ at $500^{\circ} \mathrm{C}$ had small bands at $1550,1200-1300$, and $1000 \mathrm{~cm}^{-1}$. This showed the presence of aliphatic carboxylic acid salt, inorganic nitrate $\left(\mathrm{NO}_{3}^{-}\right)$, and inorganic phosphate groups (Figure 4). The presents of aliphatic compounds suggest that these products are organic compounds that contain carbon-hydrogen bonds. These functional groups are capable of binding to other elements other than hydrogen. These include and are not limited to oxygen, sulphur, nitrogen, and chlorine [41]. Franca et al. [42] reported the presence of hydrogen, oxygen, and nitrogen atoms on the surface of the AC that can bind to other elements [3]. Mopoung et al. [40] noted the presence of $\mathrm{O}-\mathrm{H}, \mathrm{C}-\mathrm{H}, \mathrm{C}-\mathrm{O}, \mathrm{C}=\mathrm{O},-\mathrm{CO}_{3}$, and $\mathrm{Si}-\mathrm{H}$ groups on the surface of $\mathrm{AC}$ produced from tamarind seeds.

\section{Conclusion}

The synthesised AC from Marula nutshells had characteristics that were not significantly different from commercial type AC. The carbon yield and total carbon values of samples activated using $\mathrm{H}_{2} \mathrm{SO}_{4}$ and $\mathrm{H}_{3} \mathrm{PO}_{4}$ were $32.2-93.2 \%$, $26.9-95.8 \%$, and $46-79 \%, 20.8-69.8 \%$, respectively. The temperature of activation has a bearing on the yield of the activated carbon. The optimum temperature from Marula nutshells using activation agents was found to be $500^{\circ} \mathrm{C}$. AC treated with $40 \% \mathrm{H}_{3} \mathrm{PO}_{4}$ had the highest iodine value of $1075.7 \mathrm{mg} / \mathrm{g}$. FTIR analysis indicated the presence of primary amine group $(\mathrm{N}-\mathrm{H})$, aliphatic hydrocarbons, and anhydride (CO-O-CO) groups in untreated Marula nutshell powder. Furthermore, aliphatic carboxylic acid salt, inorganic nitrate $\left(\mathrm{NO}_{3}^{-}\right)$, and inorganic phosphate groups were present in synthesised AC samples activated using $40 \%$ $\mathrm{H}_{3} \mathrm{PO}_{4}$ at $500^{\circ} \mathrm{C}$. The carbonization process might have removed some functional groups in the raw material. A novel adsorbent was synthesised from Marula nutshells with the potential of being used in water treatment. There is a need to conduct further research on the potential of the synthesised AC from Marula nutshells on the removal of As, $\mathrm{Pb}$, available chlorine, and reduction of bacterial load in contaminated water.

\section{Data Availability}

The data sets of this research are available and will be provided upon request.

\section{Conflicts of Interest}

The authors declare there are no conflicts of interest.

\section{Acknowledgments}

The authors would like to thank the Manager for the Chemical and Foods Technology Division (P. Mubika) at the Standards Association of Zimbabwe for her support. Special thanks are due to SIRDC, the Chemistry Division, for assisting with the FTIR characterisation. Special thanks are due to A.P. Mahachi, G. Rongai, and P. Maringa for their technical competencies.

\section{References}

[1] K. Ukanwa, K. Patchigolla, R. Sakrabani, E. Anthony, and S. Mandavgane, "A review of chemicals to produce activated carbon from agricultural waste biomass," Sustainability, vol. 11, no. 22, p. 6204, 2019.

[2] A. Min and A. T. Harris, "Influence of carbon dioxide partial pressure and fluidization velocity on activated carbons prepared from scrap car tyre in a fluidized bed," Chemical Engineering Science, vol. 61, no. 24, pp. 8050-8059, 2006.

[3] A. L. Cazetta, A. M. M. Vargas, E. M. Nogami et al., "NaOHactivated carbon of high surface area produced from coconut shell: kinetics and equilibrium studies from the methylene blue adsorption," Chemical Engineering Journal, vol. 174, no. 1, pp. 117-125, 2011.

[4] A. C. Lua and J. Guo, "Microporous oil-palm-shell activated carbon prepared by physical activation for gas-phase adsorption," Langmuir, vol. 17, no. 22, pp. 7112-7117, 2001.

[5] A. Verla, M. Horsfall (Jnr), E. N. Verla, A. I. Spiff, and O. A. Ekpete, "Preparation and characterization of activated carbon from fluted pumpkin (telfairia occidentalis hook.F) seed shell," Asian Journal of Natural \& Applied Sciences, vol. 1, no. 3, pp. 39-50, 2012.

[6] P. Sugumaran, V. P. Susan, P. Ravichandran, and S. Seshadri, "Production and characterization of activated carbon from banana empty fruit bunch and delonix regia fruit pod," Journal of Sustainable Energy \& Environment, vol. 3, no. 3, pp. 125-132, 2012.

[7] Y. Lu, J. Yuan, X. Lu et al., "Major threats of pollution and climate change to global coastal ecosystems and enhanced management for sustainability," Environmental Pollution, vol. 239, pp. 670-680, 2018.

[8] C. Orwa, A. Mutua, R. Kindt, R. Jamnadass, and A. J. Simons, "Agroforestry tree database: a tree reference and selection guide version 4.0," ICRAF Science Domain 3 (Tree Domestication, Diversity and Delivery), 2009.

[9] A. T. Kugedera, "Assessing the distribution and stem densities of sclerocarya birrea in arable and non-arable lands: a case of Zimbabwe," Acta Scientific Microbiology, vol. 2, pp. 59-66, 2019. 
[10] G. Prinsloo and R. A. Street, "Marula [sclerocarya birrea (a.rich) hochst]: a review of traditional uses, phytochemistry, and pharmacology," ACS Symposium Series, vol. 1127, pp. 19-32, 2013.

[11] A. Maroyi, "Local knowledge and use of Marula [sclerocarya birrea (a. rich.) hochst.] in South-central Zimbabwe," Indian Journal of Traditional Knowledge, vol. 12, no. 3, pp. 398-403, 2013.

[12] Plant for a Future (PFAF), "Sclerocarya birrea-(a.rich.) hochst. plant for a future," 2021, https://pfaf.org/user/Plant. aspx? LatinName=Sclerocarya+birrea.

[13] A. A. Mariod and S. I. Abdelwahab, "Sclerocarya birrea (marula), an african tree of nutritional and medicinal uses: a review," Food Reviews International, vol. 28, no. 4, pp. 375-388, 2012.

[14] A. Stone, A. Massey, M. Theobald et al., Africa's Indigenous Crops (No. BOOK), Worldwatch Institute, Washington, DC, USA, 2011.

[15] J. N. Edokpayi, S. S. Ndlovu, and J. O. Odiyo, "Characterization of pulverized Marula seed husk and its potential for the sequestration of methylene blue from aqueous solution," BMC Chemistry, vol. 13, no. 1, pp. 1-14, 2019.

[16] N. Arena, J. Lee, and R. Clift, "Life cycle assessment of activated carbon production from coconut shells," Journal of Cleaner Production, vol. 125, pp. 68-77, 2016.

[17] A. E. Burakov, E. V. Galunin, I. V. Burakova et al., "Adsorption of heavy metals on conventional and nanostructured materials for wastewater treatment purposes: a review," Ecotoxicology and Environmental Safety, vol. 148, pp. 702-712, 2018.

[18] I. Raya and M. Zakir, "The adsorption of $\mathrm{Pb}$ (II) ions on activated carbon from rice husk, irradiated by ultrasonic waves: kinetic and thermodynamics studies," Journal of Natural Sciences Research, vol. 4, no. 2, pp. 18-24, 2014.

[19] G. O. El-Sayed, M. M. Yehia, and A. A. Asaad, "Assessment of activated carbon prepared from corncob by chemical activation with phosphoric acid," Water Resources and Industry, vol. 7-8, pp. 66-75, 2014.

[20] O. A. Ekpete, A. C. Marcus, and V. Osi, "Preparation and characterization of activated carbon obtained from plantain (Musa paradisiaca) fruit stem," Journal of Chemistry, vol. 2017, Article ID 8635615, 6 pages, 2017.

[21] D. Pavlenko, D. Giasafaki, G. Charalambopoulou et al., "Carbon adsorbents with dual porosity for efficient removal of uremic toxins and cytokines from human plasma," Scientific Reports, vol. 7, no. 1, pp. 1-7, 2017.

[22] D. R. Barai and V. K. Jha, "Preparation of activated charcoal adsorbent from waste tire," Scientific World, vol. 10, no. 10, pp. 80-83, 2012.

[23] ASTM D2854-96, Standard Test Method for Apparent Density of Activated Carbon, ASTM International, West Conshohocken, PA, USA, 2000, http://www.astm.org.

[24] ASTM D2867-04, Standard Test Methods for Moisture in Activated Carbon, ASTM International, West Conshohocken, PA, USA, 2004, http://www.astm.org.

[25] ASTM D2866-11, Standard Test Method for Total Ash Content of Activated Carbon, ASTM International, West Conshohocken, PA, USA, 2018, http://www.astm.org.

[26] A. H. Abdullah, A. Kassim, Z. Zainal et al., "Preparation and characterization of activated carbon from gelam wood bark (Melaleuca cajuputi)," Malaysian Journal of Analytical Sciences, vol. 7, no. 1, pp. 65-68, 2001.
[27] H. Chen, "Chemical composition and structure of natural lignocellulose," in Biotechnology of Lignocellulose, pp. 25-71, Springer, Berlin, Germany, 2014.

[28] M. Danish and T. Ahmad, "A review on utilization of wood biomass as a sustainable precursor for activated carbon production and application," Renewable and Sustainable Energy Reviews, vol. 87, pp. 1-21, 2018.

[29] J. Sanchez, Characterization of Activated Carbon Produced from Coffee Residues by Chemical and Physical Activation, Chemical Science and Engineering, Stockholm, Sweden, 2011.

[30] A. Achebi Se, C. E. Gimba, A. Uzairu, and Y. A. Dallatu, "Preparation and characterization of activated carbon from palm kernel shell by chemical activation," Research Journal of Chemical Sciences, vol. 3, no. 7, pp. 54-61, 2013.

[31] C. Qin, K. Clarke, and K. Li, "Interactive forces between lignin and cellulase as determined by atomic force microscopy," Biotechnology for Biofuels, vol. 7, no. 1, pp. 1-10, 2014.

[32] Y. Örkün, N. Karatepe, and R. Yavuz, "Influence of temperature and impregnation ratio of $\mathrm{H}_{3} \mathrm{PO}_{4}$ on the production of activated carbon from hazelnut shell," Acta Physica Polonica A, vol. 121, no. 1, pp. 277-280, 2012.

[33] L. Huang, Y. Sun, W. Wang, Q. Yue, and T. Yang, "Comparative study on characterization of activated carbons prepared by microwave and conventional heating methods and application in removal of oxytetracycline (OTC)," Chemical Engineering Journal, vol. 171, no. 3, pp. 1446-1453, 2011.

[34] J. T. Nwabanne and P. K. Igbokwe, "Preparation of activated carbon from nipa palm nut: influence of preparation conditions," Research Journal of Chemical Sciences, vol. 1, no. 6, pp. 53-58, 2011.

[35] S. A. Nicolae, H. Au, P. Modugno et al., "Recent advances in hydrothermal carbonisation: from tailored carbon materials and biochemicals to applications and bioenergy," Green Chemistry, vol. 22, no. 15, pp. 4747-4800, 2020.

[36] O. A. Ekpete and M. J. N. R. Horsfall, "Preparation and characterization of activated carbon derived from fluted pumpkin stem waste (Telfairia occidentalis hook F)," Research Journal of Chemical Sciences, vol. 1, no. 3, pp. 10-17, 2011.

[37] J. Sahira, A. Mandira, P. B. Prasad, and P. R. Ram, "Effects of activating agents on the activated carbons prepared from lapsi seed stone," Research Journal of Chemical Sciences, vol. 3, no. 5, pp. 19-24, 2013.

[38] S.-Q. Li, Q. Yao, S.-E. Wen, Y. Chi, and J.-H. Yan, "Properties of pyrolytic chars and activated carbons derived from pilotscale pyrolysis of used tires," Journal of the Air \& Waste Management Association, vol. 55, no. 9, pp. 1315-1326, 2005.

[39] S. Sharada, N. B. Sri, K. Supriya, M. Venkatesh, and M. Srihari, "Adsorption of toxicants (chromium, iron and oxalic acid) on activated carbons prepared from tamarind seeds," International Journal for Scientific Research and Development, vol. 1, no. 5, pp. 274-283, 2016.

[40] S. Mopoung, P. Moonsri, W. Palas, and S. Khumpai, "Characterization and properties of activated carbon prepared from tamarind seeds by $\mathrm{KOH}$ activation for Fe (III) adsorption from aqueous solution," The Scientific World Journal, vol. 2015, Article ID 415961, 9 pages, 2015.

[41] IUPAC, Aliphatic Compounds, Compendium of Chemical Technology, The Gold Book, New York, NY, USA, 2nd edition, 1997.

[42] A. S. Franca, L. S. Oliveira, A. A. Nunes, and C. C. O. Alves, "Microwave assisted thermal treatment of defective coffee beans press cake for the production of adsorbents," Bioresource Technology, vol. 101, no. 3, pp. 1068-1074, 2010. 